UNITED STATES DEPARTMENT OF THE INTERIOR

Harold L. Ickes, Secretary

GEOLOGICAL SURVEY

W. E. Wrather, Director

Bulletin 936-Q

\title{
THE COSO QUICKSILVER DISTRICT INYO COUNTY, CALIFORNIA
}

BY

CLYDE P. ROSS AND ROBERT G. YATES

Strategic Minerals Investigations, 1942

(Pages 395-416)

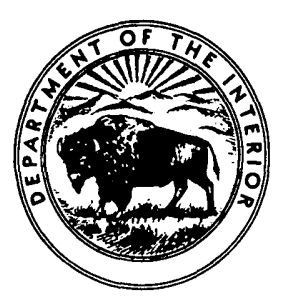

UNITED STATES

GOVERNMENT PRINTING OFFICE

WASHINGTON : 1943

For sale by the Superintendent of Documents, U. S. Government Printing Office, Washington, D. C. Price 40 cents 


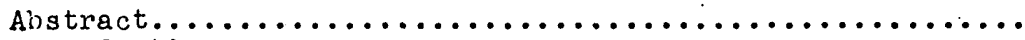

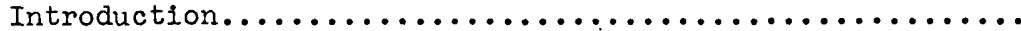

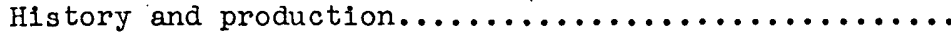

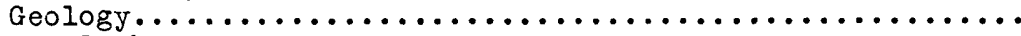

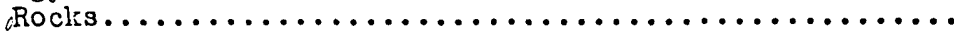

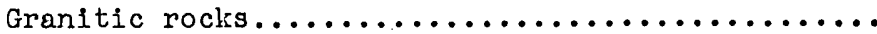
Rhyolitic and related flows $\ldots \ldots \ldots \ldots \ldots \ldots \ldots \ldots$

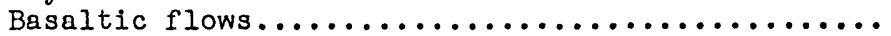

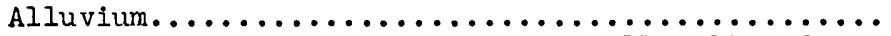
Hot-spring deposits and hydrothermally altered

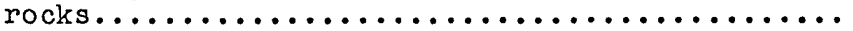

Siliceous sinter......................

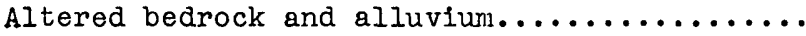

Hot springs and fumaroles................

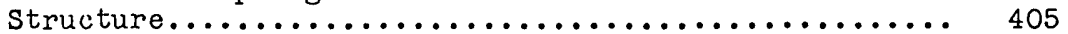

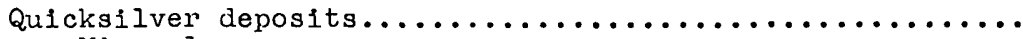

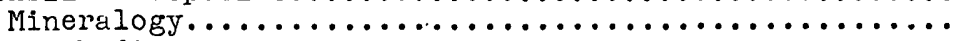

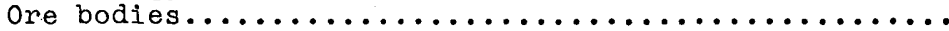

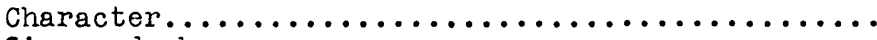

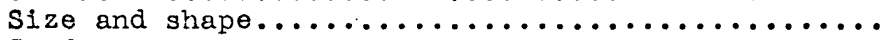

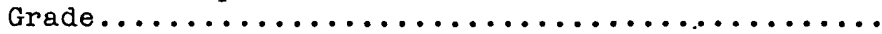

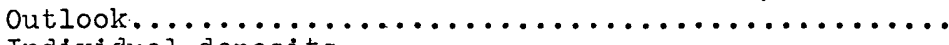

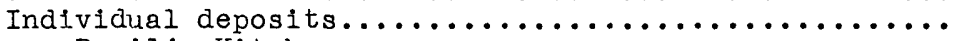

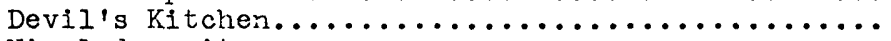

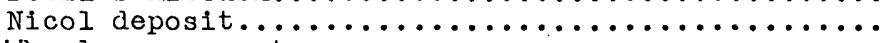

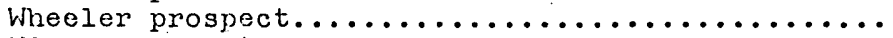

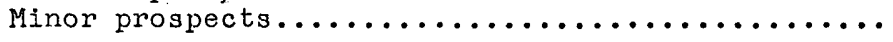

411

412

412

413

414

415

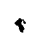 \\ ILLUSTRATIONS}

Page

Plate 58. Index map of southern California........... 398

59. Geologic reconnaissance map of the Coso district and vicinity, Inyo County, Calif........

60. Qeologic and topographic map of the Coso quicksilver property, Inyo County, Calif....... In pocket

61. Geologic and topogranhic map of the wheeler prospect and vicinity, Inyo County, Calif..... 
THE COSO QUICKSILVER DISTRICT,

INYO COUNTY, CALIFORNIA

By Clyde P. Ross and Robert G. Yates

ABSTRACT

The Coso quicksilver district, which is in the Coso Range, Inyo County, Calif., produced 231 flasks of quicksilver between 1935 and 1939. The quicksilver mineral, cinnabar, was not recognized in the district until 1929, although the hot springs near the deposits have been known since about 1875.

There are three hot-spring deposits in the district, known respectively as the Devil's Kitchen, Nicol, and Wheeler deposits, that contain cinnabar in appreciable quantities, and there are several minor deposits in which cinnabar appears to be rare or a'ssent. These mineralized areas are characterized oy hot springs and fumaroies that represent the latest stage of Pleistocene and Recent volcanism, which is otherwise manifested throughout the region by numerous rhyolitic and basaltic flows and cones. These volcanic rocks rest upon the eroded surface of the Sierra Nevada composite batholith.

Most of the quicksilver deposits are in accumulations of siliceous sinter deposited by hot springs, but some of them are in alluvium that has been kaolinized and silicified by solfataric action. The sinter deposits consist mainly of opal, but include some kaolin, minor quantities of other minerals, and widely but sparsely distributed sand and pebbles.

The granitic rock on which much of the sinter rests is considerably altered. The cinnabar was deposited as films and grains in open spaces in the sinter, during one stage in a sequence of hot spring activities that still continues.

The amount of sinter in the district is estimated to be about 1,800,000 tons. Although the greater part of this does not contain much cinnabar, the total quantity of such material is large enough to be of interest as a low-grade ore.

\section{INTRODUCTION}

The Coso quicksilver district, which is in the Coso Range, In the southwestern corner of Inyo County, Callf. (see pl. 58), contains several deposits of cinnabar in hot spring sinter. Mining and exploration have been largely confined to the Nicol and Devil's Kitchen properties, which are about 2 miles southwest of Coso Hot Springs (pls. 58 and 59). Several prospects in 
which cinnabar has been exposed lie farther west, mainly in T. 22 S., R. 38 E., and the wheeler prospect is nearly 2 miles southeast of the Devil's Kitchen. Good gravel roads connect Coso Hot Springs and the quicksilver-bearing areas with U. S. Highway 395 and the Southern Pacific Rallroad at Little Lake and Coso Junction.

This report briefly describes the geology of the quicksilver deposits and considers the probable future of the district. The relatively undeveloped state of the deposits has made it impossible to obtain sufficient reliable data on which to base estimates of the grade of ore. After the Survey's field work was completed; however, extensive exploration and sampling were carrled out by the Bureau of Mines, United States Department of the Interior.

This report_is based on a brief visit by Ross in 1939 and an examination by Ross and Yates that occupied about one month in the summer of 1940. Both men worked together in the detailed mapping, but the geologic reconnaissance map (pl. 59) was made by Yates. The hearty cooperation of F. J. Sanders, Mark Dailey, and others interested in the district is appreciatively acknowledged. Clarence S. Ross, of the Geological Survey, contributed much valuable information on the character of the clay minerals, and J. J. Fahey, also of the Geological Survey, made determinations on the quicksilver content of the sinter.

\section{History and production}

The thermal springs with which the deposits are associated have been known to white men since about 1875.I/ The presence in the Coso region of the quicksilver-bearing mineral cinnabar and of sulfur was not recognized until about 1929, when

\footnotetext{
1/ Wheeler, G. M., Annual report upon the geographlcal surveys west of the looth meridian in Cajlfornia, Nevada, Utah, Colorado, Wyoming, New Mexico, Arizona, and Montana, p. 194, Washington, 1976.
} 
F. J. Sanders, who controlled the principal group of springs at the Coso Hot Springs resort, discovered cinnabar first in the themnal area known as the Devil's Kitchen and later at the Nicol property. Many shallow trenches were dug at both locallties during 1929 for the purpose of sampling the deposits, $2 /$ and a little quicksilver was produced in 1931 and 1932. In 1935 a battery of Johnson-McKay retorts with a daily capacity of 1 ton of ore was installed on a knoll between the Devil's Kitchen and Nicol properties. It operated seven months on selected ore. Early in 1938 a Herreschoff furnace with a daily capacity of 25 tons was erected on the site of the retorts and a small power shovel was put in operation at the Devil's Kitchen. 3 / This plant operated for a period of five months during 1933 and early 1939. Most of the ore treated was taken from a pit, having an area of about 400 square feet, in the Devil's Kitchen, and the chute shown in plate 60 presurnably leads from this pit. These operations ceased in 1939, and the furnace was removed from the property in July 1940. Failure to continue the work, despite the high prices for quicksilver which prevailed throughout 1940 and 1941, was due in part to metallurgical difficulties encountered in treating the somewhat unusual ore.

According to records of the California State Division of Mines that were kindly furnished by $W$. W. Bradley, state mineralogist, the Coso district produced 231 flasks of quicksilver, worth $\$ 16,865$, between 1931 and 1940. Of this total, 92 flasks were taken from the retorts in 1935 and 124 from the furnace in 1938 and 1939.

2/ Narner, Thor, Nercury deposit in Coso Range, Inyo County, Calfe.: Miniñe in Celifornia (Celifornia, Dept. Nat. Res., Div. Mines), vol. 26, No. $1,1930$.

3/ Pucker, W. B., and Sampson, R. J., Mineral. resources of Inyo County, Califf.: California Div. Uilnes, Jour. Mines and Geology, vol. 34, No. 4, pp. 460-462, 1938 . 


\section{GEOLOGY}

The entire region is underlain by a complex of granitic rocks, which form part of the Sierra Nevada batholith, but these rocks are covered in places by lava, hot-spring deposits, and alluvium. The volcanic rocks, whlch were extruded to form cones and lava flows, rest on a surface of rolling hills and low mountains produced by profound erosion of the granitic rocks. Fragments of obsidian and pumice were strewn over the countryside by eruptions of explosive violence. Several stages of volcanism are represented by different kinds of rhyolitic and basaltic rocks. The latest flows, which are basaltic, have scarcely been affected by erosion.

The latest stage of the volcanic activity is represented by hot springs and fumaroles, from several of which acid water and steam are still 1ssuing. The granitic bedrock and the alluvium In the vicinity of some of these springs were locally altered to clay minerals. Some of the springs formed deposits of siliceous sinter and of calcareous tufa, and cinnabar, also deposited by the rising hot waters, is irregularly distributed through the siliceous sinter.

Scattered evidence, much of it based on local land forms, strongly suggests that the rocks of the Coso Range are broken along a series of faults that trend northwest. There is also some evidence of the existence of a complementary set of fractures trending. northeastward.

\section{Rocks}

Granitic rocks

The granitic rocks are mainly gray, moderately coarse grained granodiorite and quartz monzonite, which locally contain numerous dark streaks and a few masses of nearly black metamorphic rocks. In some localities, as in the vicinity of the 
BULLETIN 938 PLATE 58

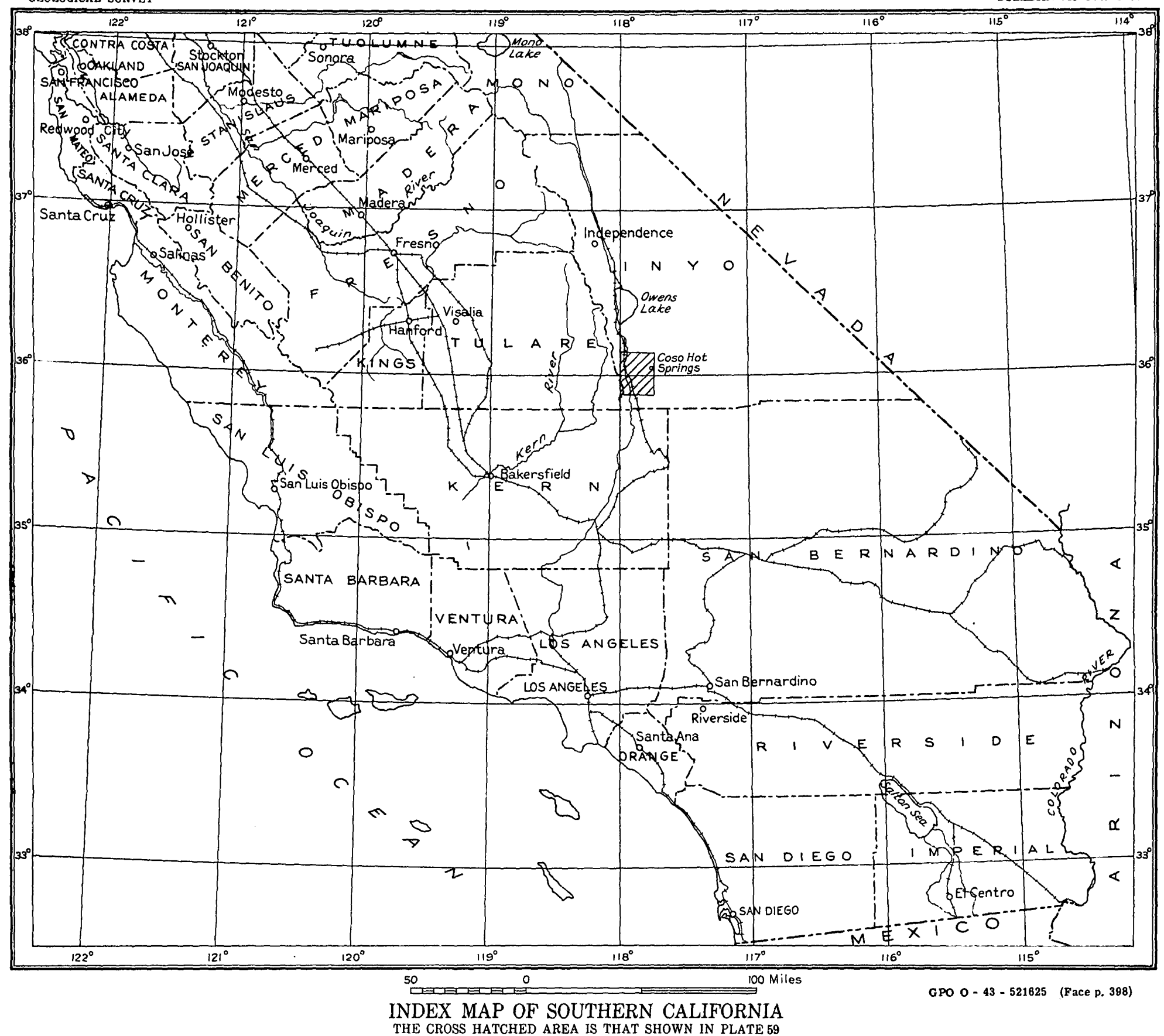




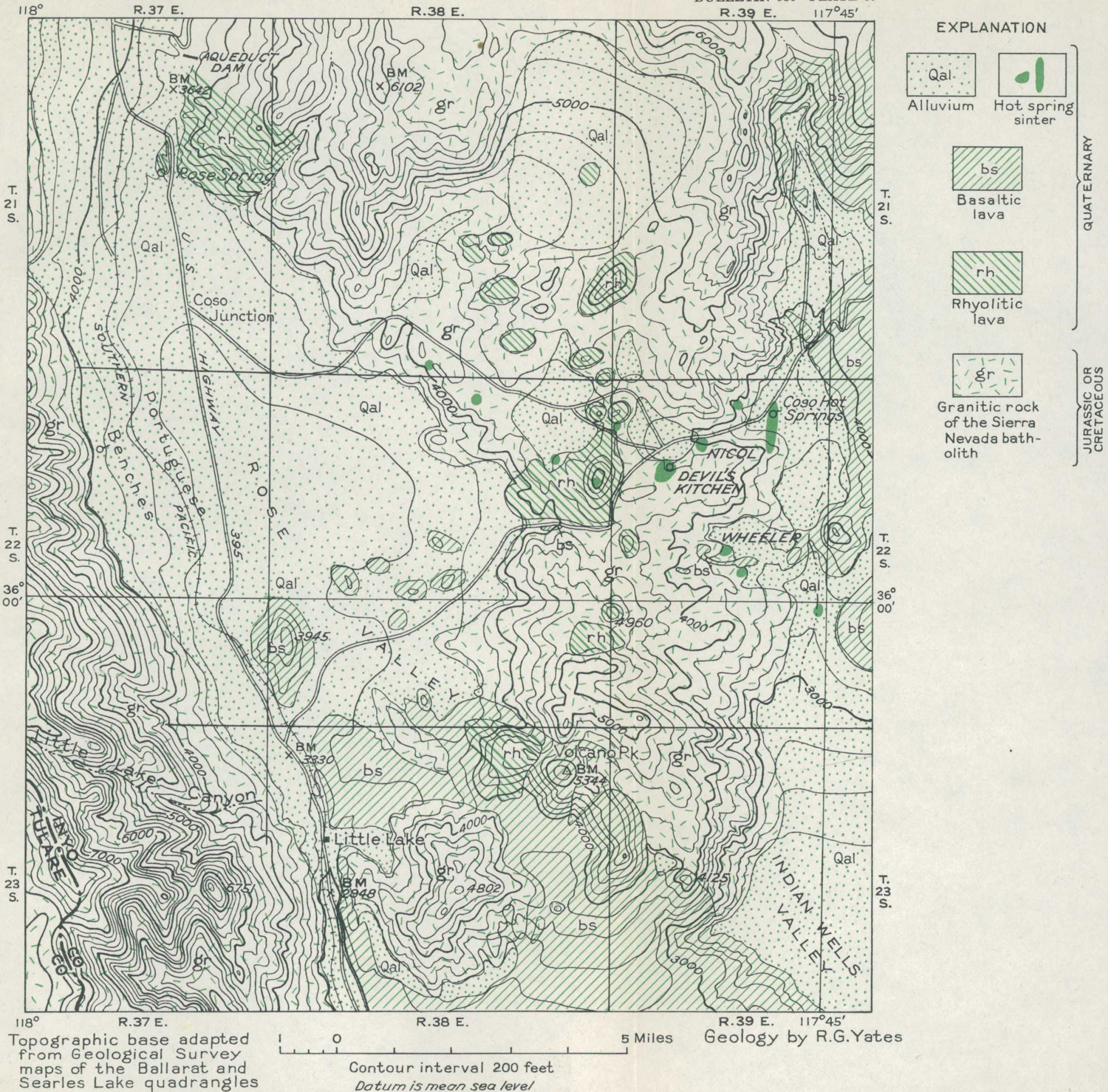


Wheeler prospect, the bedrock is white to pink and is probably close to granite in composition. Irregular masses and stringers of aplite and pegmatite and small veins of coarse-grained quartz are widely distributed throughout the mapped area, but they are commonly inconsplcuous. There are also a few dark lamprophyric dikes, one of them on the hill just east of the Devil's Kitchen.

Although the granitic rocks presumably are part of the great composite batholith of the Sierra Nevada, which is believed to have been emplaced at about the end of the Jurassic period, 4 / no evidence of their age was obtained in the area studied.

Rhyolitic and related flows

All the rhyolitic and related volcanic rocks are grouped together in plate 59, although it is recognized that some are distinctly younger than others and that there are marked differences in composition between different flows. The older and larger part of the rhyolitic rocks forms cones and plugs, and lava flows that extend only short distances from the centers of eruption. A few flows are light-colored, but most of them are black, dark gray, or greenish gray. Some consist largely or wholly of obsidian, and the rest have much glass in the groundmass. Ferromagnesian minerals are absent or scarce in all but a few flows.

Sharp-edged fragments of obsidian and pumice are widely but sparsely scattered over the countryside, giving evidence that some of these older rhyolitic rocks were erupted with explosive, violence. Undrained topographic depressions in the granitic rocks, some of them around lava cones, were probably formed by subsidence during and after the extrusion of the lavas.

4/ Knopf, Adolph, The Kother Lode system of California: U. S. Geol. Survey Prof. Paper 157, pp. 8-10, pl. 3, 1929.

Matthes, F. E., Geologic history of the Yosemite Valley; with appendix by F. C. Calkins, The granitic rocks of the Yosemite region: U. S. Feol. Survey Prof. Paper 160, pp. 22-27, 120-121, pl. 51, 1930. 
The younger rhyolitic flows were erupted late in the volcanic sequence, after much of the basalt had been extruded, and some of these flows contain inclusions of basalt. Most of them consist largely of glass, although they have not the glistening appearance of much of the earlier obsidian and differ from it also in being mostly light-colored. Some of them came from the same centers of eruption as the older flows, but some formed now crater-topped cones. Locally the rhyolitic lava is coated with loose fragments of pumice.

\section{Basaltic flows}

Basaltic rocks occur along the eastern and southern borders of the napped area. These rocks, which have an aggregate thickness of more than 1,000 feet, were extruded during two periods, separated by a period of rhyolitic eruption. The two groups of basaltic rocks are very similar in composition and character, and the intervening rhyolite, not being widely distributed, is of Iittle service in distinguishing them; it therefore was not feasible to distinguish the older and younger groups in plate 59 , where, moreover, a few flows of relatively silicic composition are included with the basaltic rocks. In the field, however, much of the later basalt can readily be recognized by its unweathered appearance.

In the general vicinity of Volcano Peak, basaltic and probably also andesitic lava and cinders were erupted from a number of craters, from which they spread to fill the lower end of Rose Valley and the upper part of Indian Wells Valley. Pyroclastic material of similar composition remains locally within the craters of the older rhyolitic cones.

Both ropy and blocky varieties of lava are represented in the later basaltic flows, most of which reached the surface through pre-existing emptive centers. Much of the lava is vesicular and some is highly scoriaceous. Pressure ridges and 
spatter cones dot the flow surfaces, and columnar structures are conspicuous in the thicker flows.

The late flows are almost unweathered, and several of them lie in the present valleys, where they block the stream channels more or less completely. Many of the younger basaltic and rhyoIitic cones are breached on the south and southwest sides, in such a manner as to suggest that their conduits plunge to the north or northeast.

Although it is evident that they are geologically young, having been extruded onto a surface made up of rolling hills and low mountains after the granitic rocks had been deeply eroded, the volcanic rocks cannot be precisely dated. The older rhyolitic rocks resemble those of the late Pleistocene Mono Craters 5 In composition and form, and they may be of the same age. The youngest flows, which fill modern valleys, cannot be older than Pleistocene and may even be Recent.

\section{Alluvium}

Gravel, sand, and silt are widespread in the valleys of the region, but only the larger bodies of alluvium are distinguished In plate 59. The central parts of most of the larger valleys are floored with playa silt. The alluvium in Rose Valloy may be moderately thick. This valley lies at the foot of the sierra Nevada and may once have been blocked at its southern end by the basaltic flow near little Lake. The alluvium in the other valleys of the region, which is made up almost exclusively of fragments of the local granitic and volcanic rocks, is probably shallow, for knobs of Eranitic rock, not shown in plate 59, project through 1 t.

5/ Putnam, w. C., The Mono Craters, Calif.: The Geographical Review, vol. 28, No. 1, pp. 71-79, 1938. 
Hot-spring deposits and hydrothermally altered rocks

The cinnabar occurs in hot-spring deposits and in adjacent hydrothermally altered granitic rocks. A dozen hot-spring deposits are shown in plate 59. Siliceous sinter is particularly abundant at the Devil's Kitchen locality but somewhat less so in the Nicol and Wheoler areas. Sereral smaller bodies of siliceous sinter lie south and west of Coso Hot Springs and along the east edge of T. 22 S., R. $38 \mathrm{E}$. In most of these places, especially at the Nicol property, the granitic bedrock and some of the alluvium over it have been partly or completely altered to clay and silica.

There are small deposits of calcareous tufa in sec. 27, T. 22 S., R. 39 E., sec。4, T. 22 S., R。 38 E., and in sec. 33, T. 21 S., R. 38 E., but as none of these is known to contain cinnabar they are not described further. In the immediate vicinity of Coso Hot Springs, neither siliceous nor calcareous deposits occur in appreciable quantity, but there is some ferruginous sludge in places, and the clayey material at some of the spring orifices may have been formed by alteration of rock or of silt by the hot waters.

Siliceous sinter.--The quicksilver-bearing siliceous sinter forms a surface mantle or blanket. Some of the material mapped as sinter consists of hydrothermally altered granitic bedrock and alluvium, which it is impracticable to map separately. The sinter varies widely in character and appearance. Earthy aggregates of loosely cemented granules of opal grade into compact opal with vitraous luster. Some of this opal is dull white and massive, but much of it forms more or less distinct layers, a few millimeters to several centimeters in thickness, that range in color from white to yellow or pink. There is little apparent system in the arrangement of the layers, and many individual layers are vuggy or minutely crinkleci and are partiy separated from adjacent layers by fairly large open 
spaces. In places the layers are irregularly curled and broken. Even where the layering is comparatively regular, adjacent layers are not strictly parallel but form a structure like that of cross-bedded sandstone. Much of the sinter encloses detrital material of various kinds. Most of the inclusions are so small that they are not readily visible. Subangular fragments of quartz, probably derived from the granitic rocks, are the most numerous. Others seem to be grains of opalized feldspar from those rocks, and some are rounded bits of lava, or angular shards of obsidian similar to those that lie loose over much of the surrounding country. Streaks of dark mica flakes are locally present but nowhere aburiant. In places the inclusions are larger, and exceptionally the sinter is crowded with rounded to subangular pebbles from one to several inches in diameter. This material, which might appropriately be called sinter conglomerate, is more abundant in the Nicol area than elsewhere. The most abundant pebbles consist of more or less thoroughly opalized granitic rock and fragments of sinter.

A selected sample of sinter as free as possible from foreign inclusions was analyzed by J. J. Fahey, who found 1t to be 89.88 percent silica, 5.74 percent water, 2.64 percent alumina, 0.20 percent ferric oxide, 0.12 percent magnesia, 0.05 percent lime, and 0.01 percent mercury. These results indicate that this sample is about 6.6 percent clay, but the proportion of clay in most of the sinter is probably somewhat higher.

Some previous investigators appear to have thought that the sinter containing cinnabar was altered rhyolite, $f$ but neither the field relations nor the petrographic character of the sinter favor such a concept.

6/ Warner, Thor, op. cit., pp. 60-62.

Tucker, W. B., and Sampson, R. J., op. cit., p. 961. Wilson, H. D. B., and Hendy, N. W., Geology and quicksilver deposits of Coso Hot Spring area (abstract): Geol. Soc. America Bull., vol. 51, No. 12 , p. 1965 , 1940 . 
Altered bedrock and alluvium.--The granitic bedrock and the alluviurn free from sinter that 1 ie beneath and along the edges of the sinter bodies have been hydrothermally altered in some places. In the ificol area (see pl. 60) much of what is mapped as hot-spring material is of this nature. If a large deposit of true sinter ever existed there it has been removed by erosion. Both the granitic bedrock and the pebbles of the alluvium have here been altered to clay and locally replaced by opal, and they are nearly white except where stained by iron oxides. The alluvial deposits include pebbles of granitic rocks, rhyolite, obsidian, and ash. Fissures in some of the brecclated granitic rock are filled with mixtures of opal and partly opalized rock fragments. At other localities veinlets of kaolinite and aggregates of fine quartz grains interspersed with flakes of a clay mineral can be seen. Much of the altered bedrock and alluvium is crumbly anci full of cavities formed by leaching, but the original texture is visible in many places. Granitic rock is represented locally by earthy white material, whose origin would be doubtful except that it grades into materlal of obviously granitic texture. Even in the most thoroughly altered rock the original quartz grains, though fractured, are unaltered. The silicate and ferromagnesian minerals, on the other hand, have been almost completely obliterated. Some holes over 40 feet in depth had not cut through the altered bedrock.

Hot springs and funaroles.--Hot springs and fumaroles are associated with most of the sinter deposits. For many years they have attracted visitors who came to drink the water and to take mid and steam baths. Irocaliy the ground is warmed by hot water or steam that does not reach the surface. The springs and funarolss are thought to represent the rinal. stages of the volcanic activity that produced in turn the lavas, the sinter deposits, and the cinnabar. They are belleved to be very 
different in cheinical composition, however, from the waters that deposited the cinnabar.

Avallable analyses of the hot-spring waters all show a high percentage of dissolved salts, and most of the samples contain a good deal of free sulfuric acld: One sample, however, collected by the writiers at Coso Hot Springs, was found to contain considerable ammonia. The waters are moderately rich in silica, but they contain no carbongies, and with one exception they are alnost free from chlorides.

Gas bubbles up through the water at Coso Hot Springs and Devil's Kitchen, and steam-laden gases rise with considerable force through small orifices at several spots in the Devil's Kitchen and Nicol areas. A sample of gas from such an orifice at the latter locality was found by $K$. J. Murata to consist of 98.1 percent carbon dioxide and 1.9 percent nitrogen and argon. No oxygen, combustibles, or hydrogen sulfide were detected in this sample, but gas from many of the fumaroles contains hydroEen sulfide and some of the steam at Coso Springs contains a small proportion of this or some other inflammable gas.

Tests with the ultraviolet lamp confirmed local opinion that black films, largely copper sulfide, deposited on copper plates exposed to the fumarole gases contained mercury. It is uncertain whether the mercury forms an amalgam with the copper or has Deen mechanically deposited as sulfide. The quantity of mercury must however be exceedingly small, for chemical tests capable of detecting as little as 0.01 percent of mercury gave negative results.

\section{$\underline{\text { structure }}$}

The geologic structure of the region is not fully known, but the rocks evidently were flexed and locally broken by disturbances that began before the volcanic eruptions and that 
continued internittertly until a very recent period. Inconclusive evidence, most of it based on local land forms, suggests that the stronger fractures and faults trend northwest. The Coso Range trends if. $45^{\circ} \mathrm{W}$. - more westerly than the nearby Slerra Nevada. Its western border is made up of several straight, more or less well defined segrnents, whicl trend in general northwestward but at considerably divergent angles, whereas the scarp that bounds the east side of the range trends almost due north. Straight-sided topographic features such as these may have resulted directly or indirectly from faulting, and faulting is further suggested by the presence of springs, both hot and cold, just east of the base of the range.

Somewhat more conclusive evidence of northwest-trending faults can be seen in the alinement of the hot springs and rhyoIitic cones within the coso Range. The four hot springs that lie closest to Rose Valley are along a line that trends N. $52^{\circ} \mathrm{W}$. , and five other's that include the Wheeler and Devil's Kitchen areas are alined N. $48^{\circ} \mathrm{W}$. (see pl. 59). The row of rilyolitic cones that extends from the northwest corner of T. 22 S., R. 39 E. across the southeast part of T. 21 S., R. 38 E. is on an extension of this same line. Furthermore, there is a southwestward-dipping zone of quartz- and pyritebearing breccia at the southeast end of the line that includes the Wheeler prospect.

The existence of northeast-trending fracture zones, complementary to those of northwest trend, is suggested by the line of springs and spring deposits that extends from the Devil's Kitchen through the Nicol area and to Coso Hot Springs. The body of sinter in the $\mathrm{Nicol}$ area is elongate toward the rortheast, and there is brocciated granitic rock on-its northwest and southeast margins. 


\section{QUICKSILVER DEPOSITS}

Cinnabar, with a little chloride of mercury, is irregularly distributed through the siliceous sinter and the associated altered granitic rocks and alluvial materials. The gangue conslsts of opal, chalcedony, and clay minerals. Sulfur, pyrite, and various hydrous sulfates, together with detrital grains of quartz and fragments of rock, occur in subordinate amount. The cinnabar lines fractures in the sinter and coats grains of quartz or granules and fragments of opal, the richest ore being in or near persistent fractures. There appears to be more cinnabar along the present stream valleys than elsewhere. The grade of the ore ranges within wide limits. In a few places there are small tonnages of material, probably workable on a small scale, that contain from 3 to 10 pounds of quicksilver to the ton, and there are also several fair-sized bodies of 2- to 3-pound ore; the average quicksilver content, however, of all the material classed as ore is less than 2 pounds to the ton.

\section{Mineralogy}

Most of the cinnabar is fine-Erained and without crystal form. Only in a few places is the disseminated cinnabar sufficlently abundant to give more than a light pink tinge to the containing rock. The mineral is light-colored in the freshest rock, but it darkens reacijly on exposure, especially in places where the sinter is molstened by escaping hot waters and gases. Although it has been shown by chemical tests that a little chloride of mercury is mingled with some of the cinnabar, no chloride minerals have been specifically identified.

Opal is by far the most abundant constituent of the sinter. It varies markedly in superficial appearance from place to place, largely because of differences in compactness and other 
features: some of 1 f forms earthy aggregates of more or less loosely cemented granules, while some is compact and has a vitreous luster. Chalcedony is present in the sinter, and in some places, notably at the Wheeler prospect, it is conspicuous; probably, however, none of the sinter contains much more than 10 percent of chalicedony, or of quartz other than as detrital grains.

A few gash veins of kaolinite cut the sinter and altered rocks in the Nicol area, and, as noted above, the underlyinf granitic bedrock and alluvium there have been largely converted to clay minerals. Similar clay mirierals are widely distributed in all the sinter, particularly at the Wheeler prospect, but on the average the clay minerals probably form less than 10 percent of the sinter. Throughout the sinter these minerals are mixed with opal, and localiy they are stalned with iron oxides or with cinnabar.

In places at the Devil's Kitchen, and less conspicuously elsewhere, there are f'ilms of sulfur on fractures in the sinter. Blocks of rather coarsely crystalline, essentially pure sulfur occur in a few spots. Delicate crystals of sulfur form craterlets around many of the gas orifices, particulariy at the Devil's Kitchen. Hyärous sulfates of different kinds, and red and yellow oxides of fron, stain the sinter and form thin crusts on fracture surfaces in the vicinity of many of the sulfur-lined orifices.

Pyrite is nowhere conspicuous. Small cules of pyrite were observed in the loose, weathered sinter surrounding one of the funaroles in the Devil's Kitchen, and fine-grained pyrite is common, though not abundant, in the altered granite at the Nicol deposit. Some of the ore contains thin dark bands of very fine grained, tarnished pyrite, or other sulfide, and Waring notes that at the time of his visit minute crystals, apparently of 
pyrite, were collecting on the water and on the clay at the main orifice of Coso Hot Springs.?

\section{Ore bodies}

Character.--As cinnabar is irregularly distributed tinrough much of the siliceous sinter and through some of the nearby altered rock and allivial material, the ore bodies may be regarded as generally coextensive with the hot spring deposits shown in plates 60 and 61 and described above.

Cinnabar lines fractures of different kinds in the sinter. Much of 1 t coats grains of quartz and other fragments of foreign material, and some of it coats granules of opal or fragments of craciked and recemented sinter. In some of the ore there are filins of cinnabar between the layers of sinter, but such films are nowhere persistent and generally end in irregular ramifying stringers. Exceptionaliy, fracture zones that range from a few inches to several feet in width are filled with relatively rich stringers of cinnabar associated with opal, quartz, and small quantities of clay. The ore stringers at the Wheeler prospect contain much kaolin, but some of the kaolin seams on $\mathrm{Nicol}$ ground are karren of cinnabar.

So far as was learned, the distribution of cinnabar within the different sinter bodies is without apparent system except in two particulars. First, the richer ore is confined to the more persistent fissures, whereas in ore of lower grade, which is decidedly more abundant, cinnabar fills smaller, more evenly distributed openings. Second, in the Devil's Kitchen area there appears to be more cinnabar in the sinter along the present streamways than elsewhere. The present hot springs are in these

7/ Waring, G. A., Springs of California: U. S. Geol. Survey Water Supply Paper 338, p. 149, 1915. 
streamways, and the position of these springs has doubtless influenced the drainage pattern; the relative abundance of cinnabar along the streamways may thus be due to deposition from these hot spings-or their ancestors. Another possibility is that the special abundance of cinnabar in the topographic lows is the result of reworking and mechanical concentration by recent surface and near-surface waters. It is possible, again, that the distribution of cinnabar may have been determined by both these agencies together.

Size and shape.--The masses of sinter differ widely in size, and their thickness and shape depend largely on the local topography. The largest mass is that of the Devil's Kitchen, which occuples a valley and has itself been trenched by a modern intermittent stream, fed in part by water from the hot springs. This mass is 2,575 feet long and 1,550 feet broad. In the deeper parts of the valley the sinter must originally have had a thickness of more than 50 and possibly as much as 100 feet, but much of 1 t has been removed by erosion. The sinter thins out along the valley flanks, and its present average thlckness is probably not more than 15 feet. The other sinter masses in the region are much smaller than that in the Devil's Kitchen, and some consist merely of superficially altered rock with thin coatings of silica.

Grade.--Cinnabar is distributed widely but irregularly and, on the whole, rather sparsely through the bodies of sinter. There had been no systematic sampling of the deposits at the time this examination was made, but the results of the former trial operations give some 1dea of the grade of the ore. From about 3,500 tons of ore which were sent through the Herreschoff furnace, the recorded yield was 124 flasks, or 9,424 pounds, indicating a recoverable quicksilver content of 2.7 pounds to the ton. Results of the earlier retort operations, on the other hand, indicate that ore of much higher grade was treated then. 
The retorts had a combined capacity of only I ton a day, so that even if they were operated at-capacity, they could have treated only about 210 tons in 7 months time. The yield for this mun was 92 flasks, or 6,992 pounds, indicating that the ore treated contained at least 33 pounds of quicksilver to the ton. But as the ore actually retorted was doubtless carefully selected, the total yield probably represents at least 1,000 tons of the grade of crude ore that would be handled in larger operations.

The few samples taken by the writers in various places serve merely to give an idea of the range in tenor of certain parts of the deposits. These samples, which will be mentioned again under the descriptions of individual deposits, showed on assay from 0.05 to 2.35 percent of quicksilver, cerresponding to 0.1 to 47 pounds to the ton. Nearly all of the assays of the ore that have been made and recorded by others fall within the limits of the writers' samples.

\section{Outlook}

According to determinations by the Bureau of Mines, a ton of the siliceous sinter in place occuples about 25 cublc feet. From this figure together with the writers' maps and estimates of the size of the deposits, the total quantity of sinter in the district is roughly computed to be about 1,800,000 tons; only a fraction of this, however, is thought to average as much as 2 pounds of quicksilver to the ton. Ore as rich as that referred to in the preceding paragraph is probably so scarce that it can be disregarded in estimating the value of the deposits. Thus it is evident that the mineralized material, although fairly abundant, could not be worked commercially at a profit unless operating and market conditions were exceptionally favorable.

Deposits of possible cómmercial interest are probably confined to the Devil's Kitchen, Nicol, and Wheeler areas. Cinnabar has been reported from several other places, and it is 
possible that the district contains undiscovered deposits, but, as the average tenor of the ore bodies is ilow, small ones probably would have little or no value. The silicified rock, also, beneath the sinter, and feeder channels which may extend far beneath present exposures, may contain cinnabar locally, but they are certainly less promising as sources of quicksilver than the large bodies of sinter on the surface.

The difficulties experienced by former operators in mining and treating the ore are not necessarily insurmountable. It will be necessary to sort the quarried material or to quarry selectively in order to prevent barren sinter from being sent to the furnace. Among factors that will add to the cost of mining as well as of reduction are the low density of the ore and the local abundance in it of sulfur, sulfates, and free acid.

\section{Individual deposits}

\section{Devil's Kitchen}

The Devil's Kitchen is in the northern part of secs. 7 and 8, T. 22 S., R. 39 E. It lies on the north slope of a hill and ranges in altitude from about 4,150 to about 4,450 feet above sea level. The sinter mass, which here fills a ravine and in places overlaps its borders, is being trenched by an intermittent stream, fed in part by hot waters rising through the sinter. The mass covers an area of $2,641,000$ square feet and has a maximum thickness of less than 100 feet. Calculations based upon the data available lead to the estimate that the mass contains $39,375,000$ cubic feet, which is equivalent to about $1,570,000$ tons of sinter.

The deposit has been explored by opening three quarries, several shallow trenches, and a short tunnel, all shown in plate 60. The smallest and most westerly quarry is about 3,000 square feet in area. The large quarry east of this one covers about 
203,000 square feet, and the upper quarry, which consists of several benches, has an area of about 105,000 square feet. Thus only a little more than one-tenth of the surface of the sinter mass has been stripped. Since much of the quarry work has been done on the slopes of gulches already incised in the sinter, the amount of material quarried is difficult to determine. The contours on a map drawn about $1929,8 /$ when very little excavation had been done, are so similar in form to the contours on corresponding parts of plate 60 that the widespread quarrying done in the period 1929-1940 cannot have greatly changed the shape of the hillside. Over much of the area covered by sinter little more has been done than to scrape off enough of the surface to expose fresh material, and probably the depth of cut nowhere exceeds 25 feet. A comparison of the size of dunps of unburned and burned sinter suggests that most of the sinter that was taken out was burned. The 92 flasks previously obtained from retorts is the product of more selective mining.

\section{Nicol deposit}

The Nicol deposit is near the middle of the northern part of sec. 7, T. 22 S., R. 39 E. The main part of the deposit is a mass of hydrothermally altered bedrock and alluvium and siliceous sinter. It rests on gently sloping ground at the lower end of the wide headwater basin of the streamway that leads towards Coso Hot Springs. To the south, on the far side of a hill, there is a much smaller area of similarly altered rock capped by a shallow deposit of sinter.

The main Nicol deposit ( $p l .60)$ has been explored by rather closely spaced trenches, cuts, and pits and by short tunnels

8/ Warner, Thor, Mercury Deposit in Coso Range, Inyo County, Calif.: Mining in California (California, Dept. Nat. Res., Div. Mines) vol. 26, No. I, p. $58,1930$. 
that penetrate its margins. The isolated mass to the south also has been trenched. Most of the excavations are less than 10 feet deep, but one shaft in the southwestern part of the main area is 44 feet deep. Its upper half is in sintery material and 1ts lower half in molst altered granitic rock. In several of the trenches, steam, mingled with other gases, rises through small orifices. A few of these orifices have been capped and the steam from them is piped into the nearby steam bath.

The main body of the deposit, exclusive of the tongue in a streamway at its southwest corner, has maximum dimensions of 1,175 by 650 feet. It covers 597,620 square feet and has an estimated volume of 4,500,000 cubic feet, roughly equivalent to 180,000 tons. These figures do not include the small body to the south.

Streaks as rich as some of those in the Devil's Kitchen are not known to occur in the $\mathrm{Nicol}$ area, although some material of very good grade was found there by Warnerg/ and by Tucker and Sampson.

\section{Wheeler prospect}

The Wheeler prospect held by F. J. Sanders and C. H. Schimpiff, is in Indian Wells Valley, near the northeast corner of sec. 20, T. 22 S., R. 39 E., and is reached by an unimproved road that passes close to Coso Hot Springs. There is a two-pipe retort on the property, in which more than a ton of selected ore is said to have been treated.

The prospect is at the east border of the Coso Range, which here as elsewhere is underlain by granitic rocks. Two small areas (see pl. 61), on opposite sides of the mouth of a gorge,

9/ Warner, Thor, op. cit., p. 63.

Tucker, W. B., and Sampson, R. J., Hineral resources of Inyo County, Calif.: California, Div. Mines, Jour. Mines and Geology, vol. 34, No. 4, p. 461, 1938. 


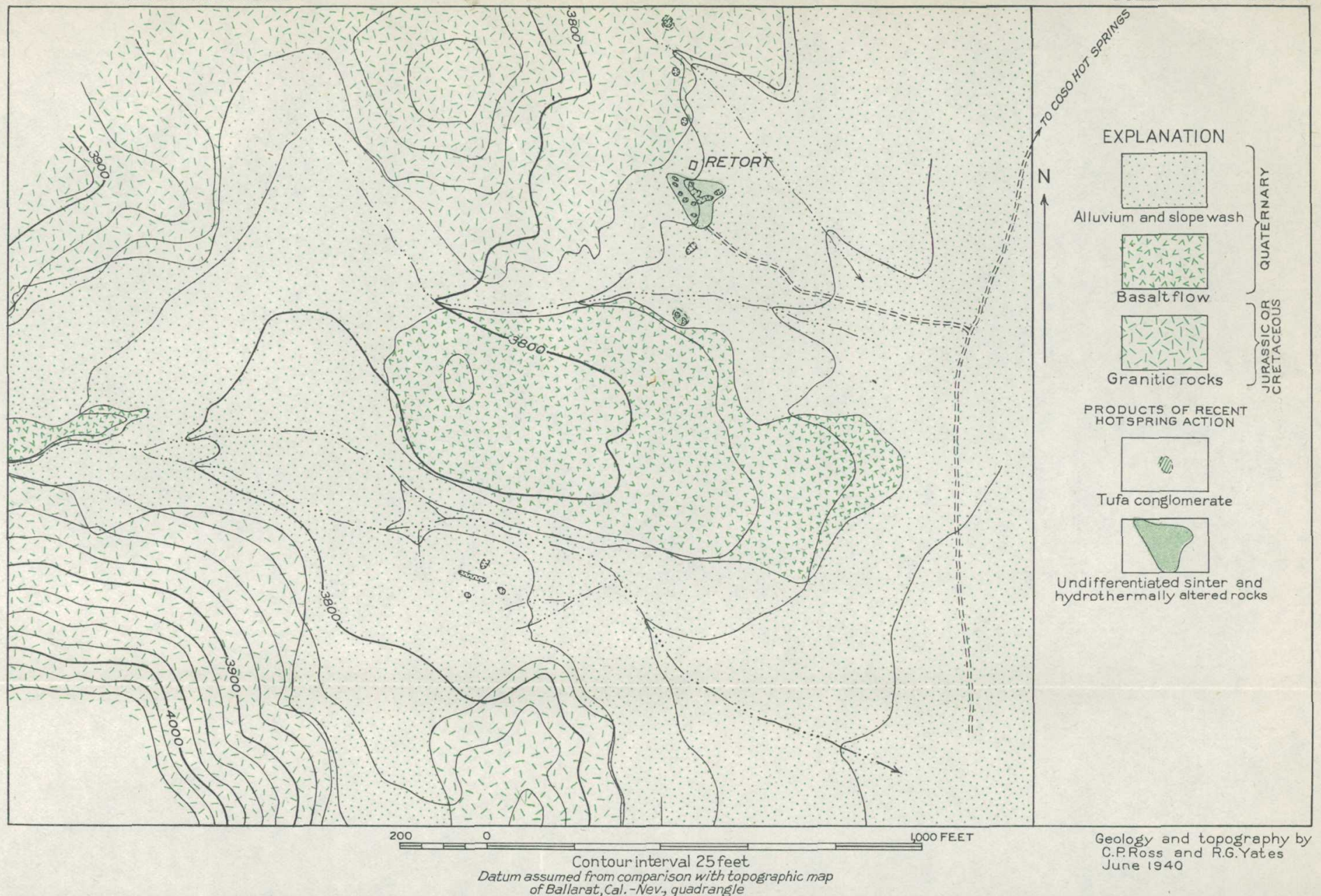


show evidence of hot-spring activity in the alluvium. Nearby are masses of recent basaltic lava. Both of the thermal areas have been trenched; but only the northern one, where the retort is situated, has yielded any quicksilver. Here the trenches have exposed a triangular mass of siliceous sinter, much of it hot and moist, with an area of about 5,000 square feet and an average thickness of fully 3 feet, which represents about 600 tons of material. Cinnabar and clay are irregulariy distributed through the sinter. Assays of samples cut by the writers, at

four places on the wall of the principal pit where cinnabar could be plainly seen, showed $0.55,0.21,0.05$, and 0.54 percent quicksilver, respectively, corresponding to $11,4,1$, and 11 pounds to the ton. The yieid sald to have been obtained from the retort operations could have been obtained only from selected ore, much richer than that represented by these samples.

Pits outside of the triangular mass expose weathered granitic rock beneath a thin cover of alluvium. A little more than 200 feet to the north, gravel cemented with calcareous tufa is exposed in a pit. This tufa, like the siliceous sinter, is doubtless a product of hot-spring action, but it is not known to contain quicksilver. The trenches and pits in the area south 1. of the basalt flow are mainly in warm iron-stained mud, which is locally encrusted with small quantities of sulfates. The surface material is largely slopewash, but granitic rock that is - only slightly weathered is exposed in several of the excavations.

Minor prospects

The small masses of sinter and silicifled granitic rock south and west of Coso Hot Springs (pl. 59) are reported to contain a little quicksilver, but they have not been developed even 
superficially. Of the five hot-spring deposits west of the Devil's Kitchen (pl. 59), at least three have been prospected for quicksilver. One of these is within the crater of a large rhyolitic cone in sec. 12, T. 22 S., R. 38 E. Cinnabar is reported to have been found in the sinter here, but it was not seen by the writers in the shallow trepches that they examined. At the second locality, on the west slope of this cone, pipes that have been driven into ground bearing some sinter emit a little steam, thus proving that thermal activity is still going on; but here, too, shallow trenches have failed to show any quicksilver. The third hot-spring deposit is in the undrained depression north of the county road close to the western border of sec. 6, T. 22 S., R. 39 E. There is a little iron-stained sinter here, but a shallow trench revealed no noticeable cinnabar. 